\title{
Communication \\ In Situ Supramolecular Gel Formed by Cyclohexane Diamine with Aldehyde Derivative
}

\author{
Jae-Hyeon Park ${ }^{1,+}$, Min-Hye Kim ${ }^{1,{ }^{\dagger}}$, Moo-Lyong Seo ${ }^{1, *}$, Ji-Ha Lee ${ }^{2, * \mathbb{C}}$ and Jong-Hwa Jung ${ }^{1, * \mathbb{C}}$ \\ 1 Department of Chemistry, Research Institute of Natural Sciences, Gyeongsang National University, \\ Jinju 52828, Korea; parkjae@gnu.ac.kr (J.-H.P.); your1005@gnu.ac.kr (M.-H.K.) \\ 2 Chemical Engineering Program, Graduate School of Advanced Science and Engineering, \\ Hiroshima University, 1-4-1 Kagamiyama, Higashi-Hiroshima 739-8527, Japan \\ * Correspondence: mlseo@gnu.ac.kr (M.-L.S.); leejiha@hiroshima-u.ac.jp (J.-H.L.); jonghwa@gnu.ac.kr (J.-H.J.) \\ + These authors contributed equally to this work.
}

Citation: Park, J.-H.; Kim, M.-H.; Seo, M.-L.; Lee, J.-H.; Jung, J.-H. In Situ Supramolecular Gel Formed by Cyclohexane Diamine with Aldehyde Derivative. Polymers 2022, 14, 400. https://doi.org/10.3390/ polym 14030400

Academic Editor:

Charles-André Fustin

Received: 15 December 2021

Accepted: 18 January 2022

Published: 20 January 2022

Publisher's Note: MDPI stays neutral with regard to jurisdictional claims in published maps and institutional affiliations.

Copyright: (C) 2022 by the authors. Licensee MDPI, Basel, Switzerland. This article is an open access article distributed under the terms and conditions of the Creative Commons Attribution (CC BY) license (https:// creativecommons.org/licenses/by/ $4.0 /)$.

\begin{abstract}
Low-molecular-weight gels have great potential for use in a variety of fields, including petrochemicals, healthcare, and tissue engineering. These supramolecular gels are frequently metastable, implying that their properties are kinetically controlled to some extent. Here, we report on the in situ supramolecular gel formation by mixing 1,3-cyclohexane diamine (1) and isocyanate derivative (2) without any catalysis at room temperature in various organic solvents. A mixture of building blocks $\mathbf{1}$ and $\mathbf{2}$ in various organic solvents, dichloromethane, tetrahydrofuran, chloroform, toluene, and 1,4-dioxane, resulted in the stable formation of supramolecular gel at room temperature within 60-100 s. This gel formation was caused by the generation of urea moieties, which allows for the formation of intermolecular hydrogen-bonding interactions via reactions $\mathbf{1}$ and $\mathbf{2}$. In situ supramolecular gels demonstrated a typical entangled fiber structure with a width of $600 \mathrm{~nm}$ and a length of several hundred $\mu \mathrm{m}$. In addition, the supramolecular gels were thermally reversible by heating and cooling. The viscoelastic properties of supramolecular gels in strain and frequency sweets were enhanced by increasing the concentration of a mixed $\mathbf{1}$ and $\mathbf{2}$. Furthermore, the supramolecular gels displayed a thixotropic effect, indicating a thermally reversible gel.
\end{abstract}

Keywords: LMOGs; supramolecular gel; urea reaction

\section{Introduction}

Gels are easily recognized as soft materials with a wide range of applications in cosmetics, pharmaceuticals, and the food industry [1]. Gelled materials are colloidal systems made up of two coexisting phases: a liquid-like phase and a solid network, with the latter preventing the liquid from flowing in bulk [2]. Recently, there has been a greater emphasis placed on understanding the self-assembly and subsequent behavior of these materials [3]. The results from these studies are used to design carefully tailored gel materials for diverse applications from tissue engineering [4-7] to nanoscale electronics [8-12]. Generally, low-molecular-weight organogelators (LMOGs) are molecules that can form thermoreversible physical gels at concentrations less than $5 \%$ gelator/weight organic solvent [13-18]. Highly anisotropic 3D structures often form fibers during gelation, but they can also form ribbons, platelets, tubular structures, or cylinders [19-22]. Gelators can be classified into two categories according to the force driving their molecular aggregation: hydrogen-bondbased gelators [23-26] and non-hydrogen-bond-based gelators [27,28] (Figure 1). Aliphatic amide [29] or urea-coupled cyclohexane [30], peptides [31-34], and sugar-based derivatives with distinct helical structures [35-37] are typical examples of the former [38-42]. In contrast, cholesterol derivatives that aggregate due to crown moieties, $\pi-\pi$ stacking, van der Waals forces, and/or solvophobic properties are a common example of the latter [43-45]. Among them, an intermolecular hydrogen-bonding interaction was utilized to prepare helical supramolecular gels. For instance, B. L. Feringa and Hanabusa groups reported 
that enantiomeric S, S-, or R, R-1,2-cyclohexane derivatives possessing two urea moieties formed organogels at low concentrations [46-49]. These cyclohexane-based gels showed the helical fiber structure with right or left helicity.

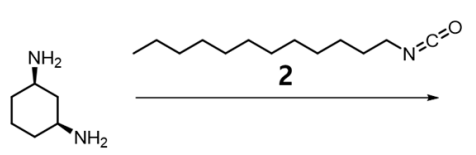

1

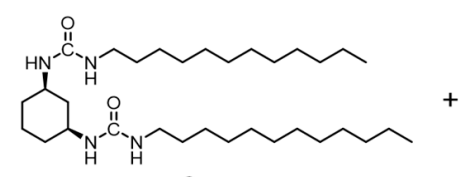

3

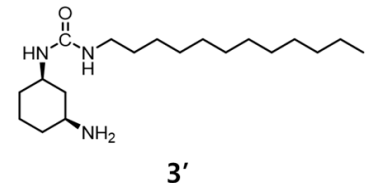

3'

Figure 1. Reaction process to form in situ supramolecular gel by mixed compounds $\mathbf{1}$ and 2.

In situ supramolecular gelator formations have recently been demonstrated typically using two-component systems that form the gelator monomer mostly through covalent or noncovalent interactions [50-60]. There are several research studies of reaction based-gel systems where the mixing of different components leads to the formation of the actual gelator. For example, J. H. van Esch and R. Eelkema et al. [61-64] reported that catalytic action could be used to control the mechanical properties of in situ supramolecular hydrogels. In addition, they demonstrated that in situ catalysis of the formation of gelator molecules can accelerate the formation of supramolecular hydrogels, which drastically enhanced their resulting mechanical properties. D. J. Adams et al. [65] reported gel formation by exploiting dynamic covalent chemistry where the simple mixing of amine and aldehyde underwent imine bond formation reaction and thereby gelation occurs. They introduced the redox-responsive hydrogel system incorporating metal ions in gel media. However, only a few examples have been reported that allow for the formation of supramolecular gels in situ without the need for additional catalysis or heating. As a result, studying supramolecular gel formation in situ remains a challenge in supramolecular chemistry.

Herein, we report in situ supramolecular gel formed by mixed 1,3-cyclohexane diamine (1) and isocyanate derivative (2) as building blocks under various organic solvent system. Gel formation was related to the interaction based on the produced urea under organic solvent ranges, respectively. The formation of in situ supramolecular gel was caused by the formation of two urea moieties, which enabled the formation of the intermolecular hydrogen-bonding interaction as a result of the reaction of building blocks (1) and (2). In addition, the mechanical properties of the supramolecular gel were observed according to the self-assembly kinetics by controlling the concentration of (1) and (2) finely. The relationship between in situ supramolecular gel formation rate and strength according to concentration is discussed in detail.

\section{Materials and Methods}

\subsection{Reagents and Instruments}

Precursors 1 and 2 were obtained from commercial suppliers (TCI, Sigma Aldrich, St. Louis, MO, USA) and used as the samples. The ${ }^{1} \mathrm{H}$ NMR spectrum was obtained with a Bruker (ARX 300, Billerica, MA, USA) using a Bruker (ARX 300). A Thermo FT-IR Nicolet iS 10 (Thermo Fisher, Waltham, MA, USA) was used to measure the FT-IR spectra in ATR in the range of $400-4000 \mathrm{~cm}^{-1}$. Mass spectroscopy samples were analyzed on a Thermo Scientific LCQ Fleet mass spectrometer.

\subsection{Preparation of Gels}

First, heat and dissolve precursor $1(9.5 \mu \mathrm{L}, 8.75 \mu \mathrm{mol})$ in organic solvents such as dimethyl sulfoxide (DMSO), acetonitrile, dichloromethane, n-hexane, or toluene (1 mL). After adding the solution to precursor $2(42.5 \mu \mathrm{L}, 17.5 \mu \mathrm{mol})$, the reaction mixture was maintained for a set period to allow gel formation.

\subsection{Preparation Method and Observation of SEM Samples}

The freeze-dried gel sample was prepared from gel ( $3 \mathrm{wt} \%$ ) by vacuum for $24 \mathrm{~h}$. Then, the dried sample was mounted on aluminum stubs (12 $\mathrm{mm}$ diameter) with carbon tape, 
and it was coated with a thin layer of Pt. FE-SEM (Tescan, Brno, Czech Republic, S8000 field emission SEM) was used to obtain images using an accelerating voltage of $10-25 \mathrm{kV}$ and an emission current of $10 \mathrm{~mA}$. We used this instrument in the National Research Facilities \& Equipment Center (2019R1A6C1010042).

\subsection{Rheological Properties}

The gels were loaded onto the rheometer plate according to the standard. Rheological properties were carried out by using AR-2000ex (TA Instruments Ltd., New Castle, DE, USA). A parallel plate with a diameter of $20 \mathrm{~mm}$ was used. The gap between the gel and the plate was set to $0.5 \mathrm{~mm}$, and the experiments were carried out at $25^{\circ} \mathrm{C}$. Strain sweep tests were carried out with increasing amplitude oscillation from $0 \%$ to $1000 \%$ apparent strain on the shear. Frequency sweeps were carried out between 0.6283 and $62.83 \mathrm{rad} \mathrm{s}^{-1}$.

\subsection{Synthesis of Compound $\mathbf{3}$}

Compound 3 was prepared by a previously reported method [66]. Dodecylisocyanate $(1.22 \mathrm{~g}, 5.7 \mathrm{mmol})$ was slowly added to a stirred solution of 1,3-cyclohexanediamine $(0.3 \mathrm{~g}, 2.6 \mathrm{mmol})$ in toluene $(30 \mathrm{~mL})$. A gel-like precipitate was formed immediately. After stirring overnight, the crude product was collected by filtration as a white waxy solid. The product was purified by resuspending the waxy solid in dichloromethane $(50 \mathrm{~mL})$, stirring for $1 \mathrm{~h}$, and collecting the product on a glass filter. This procedure was repeated when necessary. After drying at $60^{\circ} \mathrm{C}$ under vacuum, the product was obtained as a white solid in $87 \%$ yield. The product was characterized by ${ }^{1} \mathrm{H}$ NMR, FT-IR, and ESI-MS spectroscopy (Figures S1-S3). ${ }^{1} \mathrm{H}$ NMR (500 MHz, DMSO-d 6 ) $\delta 5.45(\mathrm{~s}, 1 \mathrm{H}), 5.39(\mathrm{~d}, J=6.8 \mathrm{~Hz}, 1 \mathrm{H})$, 3.39 (br, 2H), 3.06-2.98 (m, 4H), $2.04(\mathrm{~d}, J=12.2 \mathrm{~Hz}, 2 \mathrm{H}), 1.81(\mathrm{~d}, J=12.3 \mathrm{~Hz}, 2 \mathrm{H}), 1.70$ $(\mathrm{d}, J=14.1 \mathrm{~Hz}, 2 \mathrm{H}), 1.40(\mathrm{~s}, 4 \mathrm{H}), 1.30$ (d, $J=2.6 \mathrm{~Hz}, 32 \mathrm{H})$. FT-IR (ATR): 3340, 3295, 2920, 2849, $1623,1564,1464,1264,1224,722,670,636 \mathrm{~cm}^{-1}$. ESI-MS $(\mathrm{m} / z)$ : Calculated for $\mathrm{C}_{32} \mathrm{H}_{64} \mathrm{~N}_{4} \mathrm{O}_{2}$ $[\mathrm{M}+\mathrm{Na}]^{+} 559.49$, Found $[\mathrm{M}+\mathrm{NA}]^{+} 559.50$.

\section{Results and Discussion}

Urea groups are excellent hydrogen-bond acceptors and donors, providing the noncovalent interactions required for self-assembly. The hydrophobic alkane core of urea-based gelator 3 is surrounded by two hydrogen-bonding urea groups. The alkyl chains were introduced to enhance the solubility of the building block (2) and prevent crystallization of the gelator (Figure 1). Importantly, the gelator can be synthesized in situ by reacting the 1,2-cyclohexane diamine building block 1 with two molecules of aldehyde 2 . Without any catalysis, a mixture of building blocks $\mathbf{1}$ and $\mathbf{2}$ in various organic solvents such as dichloromethane, tetrahydrofuran, chloroform, toluene, and 1,4-dioxane resulted in the stable formation of supramolecular gel at room temperature within 60-100 s (Figure 2).

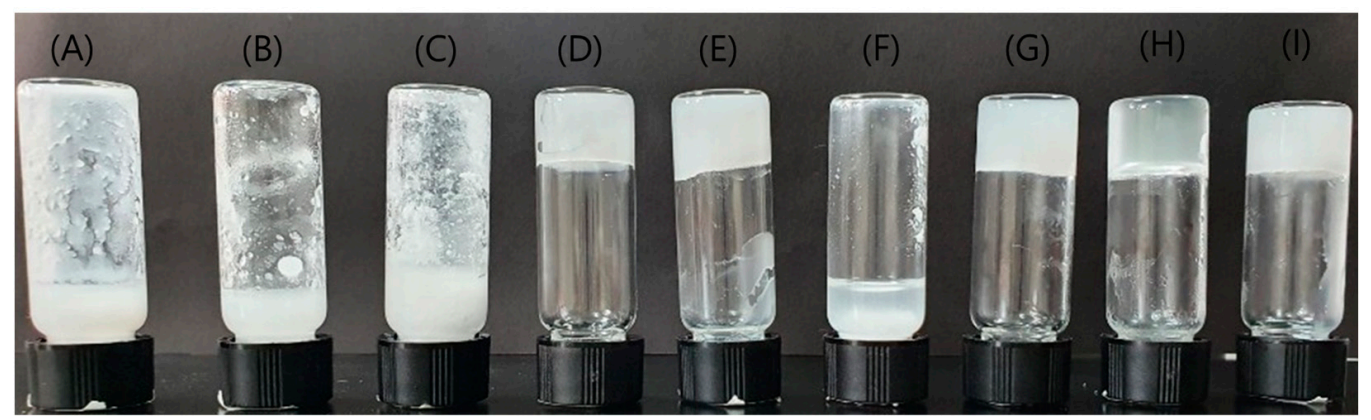

Figure 2. Photograph of supramolecular gels prepared by 1 and 2 in (A) DMF, (B) DMSO, (C) acetonitrile, (D) dichloromethane, (E) tetrahydrofuran, (F) n-hexane, (G) chloroform, (H) toluene, and (I) 1,4-dioxane.

To obtain evidence for the formation of urea groups, we used FT-IR spectroscopy to examine the FT-IR spectra of in situ supramolecular gels formed in various solvents 
(Figure S4). The medium vibration peak of -CN of 1-isocynatododecane (2) was observed at $2230 \mathrm{~cm}^{-1}$. In contrast, the medium vibration peak of $-\mathrm{CN}$ of a mixed sample consisting of building blocks 1 (1.0 Equiv.) and 2 (2.0 Equiv.) disappeared at $2265 \mathrm{~cm}^{-1}$ after $120 \mathrm{~s}$. In contrast, the $-\mathrm{C}=\mathrm{O}$ peak is generated at $1625 \mathrm{~cm}^{-1}$ (Figure $\mathrm{S} 4 \mathrm{C}$ ). This is clear evidence that urea was formed. Furthermore, the broad vibration peak of 1,3-cyclohexane diamine (1) was obtained at 3340 and $3275 \mathrm{~cm}^{-1}$, corresponding to -NH stretching, whereas a mixed sample of building blocks 1 and 2 obtained sharp peaks at 3300, $3338 \mathrm{~cm}^{-1}$, which were attributed to the generation of urea moieties by the reaction of $\mathbf{1}$ and $\mathbf{2}$. Thus, the urea moieties of gelator 3 acted as a driving force in the formation of in situ supramolecular gel. To analyze the quantitative amount of desired product 3 in situ gel obtained by a mixing 1 and 2, we prepared compound 3 and measured ${ }^{1} \mathrm{H}$ NMR spectrum in DMSO- $\mathrm{d}_{6}$ at $100{ }^{\circ} \mathrm{C}$ to prevent gel formation. As shown in Figure S5C, two different NH protons attached to the cyclohexane, and the alkyl chain groups appeared at 5.44 and 5.37 ppm, respectively. In addition, ${ }^{1} \mathrm{H}$ NMR spectrum of the xerogel sample obtained from a mixed of $\mathbf{1}$ (1.0 equiv.) and 2 (2.0 equiv.) in toluene was observed in DMSO- $\mathrm{d}_{6}$ at $100{ }^{\circ} \mathrm{C}$ (Figure S5D). As expected, two different NH protons of urea moieties appeared at 5.44 and $5.37 \mathrm{ppm}$, respectively, as obtained from pre-synthesized 3. In particular, the ratio of $\mathrm{NH}$ protons and $\mathrm{CH}_{3}$ of alkyl chain group was 2:3 by the integral ratio, indicating that the xerogel sample consists of compound 3. Based on NMR and FT observations, in situ supramolecular gel by a mixture of 1 (1.0 equiv.) and 2 (2.0 equiv.) was produced ca. 98\% of desired product 3 . In contrast, about $2 \%$ of monourea $\left(3^{\prime}\right)$ as a minar product would exist in situ gel. We also obtained the evidence of the generation of gelator 3 by electrospray ionization-mass spectroscopy (ESI-MS) (Figure S7). A sample was observed by ESI-MS after the mixed sample of $\mathbf{1}$ and $\mathbf{2}$ was kept at room temperature without stirring. The main peak was found at $m / z=559.4921$, corresponding to $[\mathbf{3}+\mathbf{H}]^{+}$. The corresponding peaks for $\mathbf{1}$ and $\mathbf{2}$ were not seen. These findings suggest that gelator $\mathbf{3}$ generated rapidly by mixing $\mathbf{1}$ and $\mathbf{2}$ at room temperature within $120 \mathrm{~s}$. Additionally, temperature-dependent proton NMR spectra were observed from 25 to $100{ }^{\circ} \mathrm{C}$ in DMSO- $\mathrm{d}_{8}$ (Figure S8). When the temperature was raised, the -NH protons attached to the urea moieties of $\mathbf{3}$ gradually shifted to a high field, which was attributed to the dissociation of the intermolecular hydrogen-bonding interaction between the urea moieties of $\mathbf{3}$. This is clear evidence that the urea moieties of $\mathbf{3}$ acted as a driving force to form in situ gel. The supramolecular gel became a transparent solution by heating $\left(110^{\circ} \mathrm{C}\right)$, and then, the solution was returned to gel at room temperature again (Figure S9), which means that the supramolecular gel was thermally reversible.

To examine the morphology of a supramolecular gel formed by a mixture of $\mathbf{1}$ and $\mathbf{2}$, we used SEM to examine samples prepared in various solvents (Figure 3 and Figure S10). The supramolecular gel showed typical entangled fiber structures with 100-700 nm of width and several hundred $\mu \mathrm{m}$ of length. There were no significant morphology changes in supramolecular gels formed in various solvents.
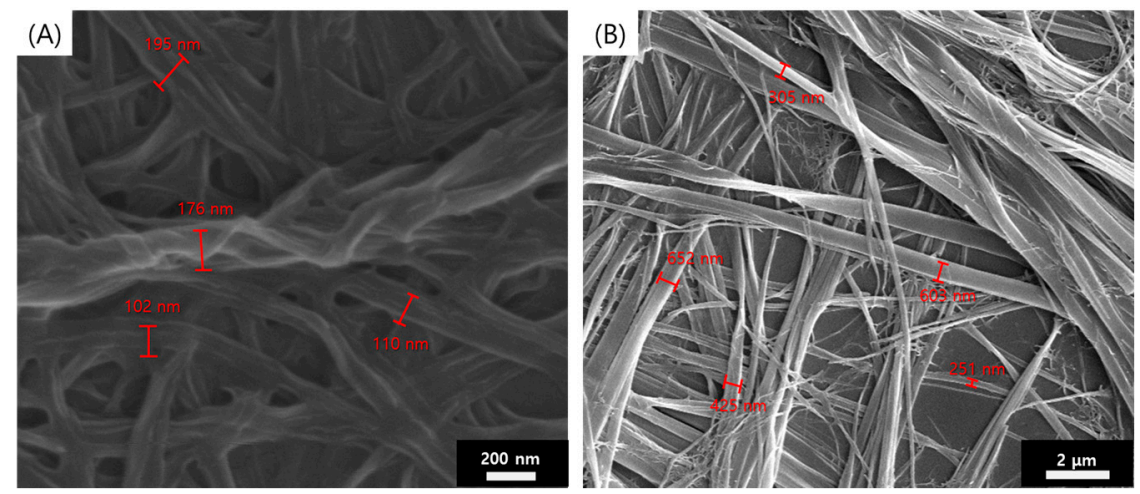

Figure 3. SEM images of in situ supramolecular gels prepared by $\mathbf{1}$ (3 wt \%) and 2 (3 wt \%) in (A) toluene and (B) n-hexane. 
Finally, we investigated the mechanical properties $\left(G^{\prime}\right.$ and $\left.G^{\prime \prime}\right)$ of the supramolecular gels in the linear viscoelastic region. The time-dependent storage $\left(G^{\prime}\right)$ and loss $\left(G^{\prime \prime}\right)$ moduli of the supramolecular gel prepared at three different concentrations of $\mathbf{1}+\mathbf{2}$ in toluene were measured (Figure 4). When mixing 1 and 2, the $G^{\prime}$ and $G^{\prime \prime}$ values of supramolecular gel (5.0 wt \%) were immediately increased, and then, these values were maintained at their maximum. On the other hand, the $G^{\prime}$ and $G^{\prime \prime}$ values of supramolecular gel (1.0 wt \%) reached a maximum after $50 \mathrm{~s}$. The $\mathrm{G}^{\prime}$ value of supramolecular gel prepared at $5.0 \mathrm{wt} \%$ was ca. 10-fold higher than that the supramolecular gel prepared at $1.0 \mathrm{wt} \%$, which was ascribed to the formation of a three-dimensional entangled fiber structure in higher concentration. The gelation time decreased as the concentration of $\mathbf{1}+\mathbf{2}$ in toluene increased, and the stiffness of the supramolecular gel increased and maintained the solid-like behavior.
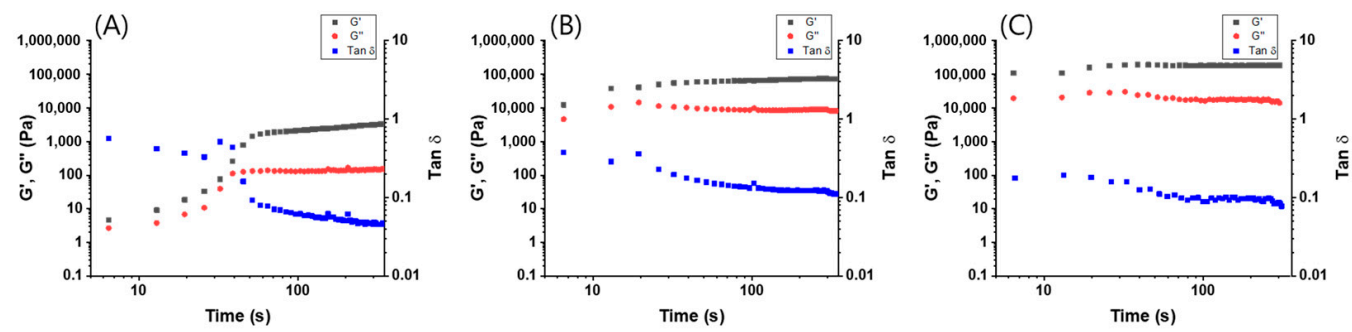

Figure 4. Time sweep (frequency $=0.6283 \mathrm{rad} \mathrm{s}^{-1}$ ) of gels obtained from (A) $\mathbf{1}(1 \mathrm{wt} \%)+\mathbf{2}$ (2 equiv.), (B) $1(3 \mathrm{wt} \%)+2$ (2 equiv.) and (C) 1 (5 wt \%) + 2 (2 equiv.) in toluene.

Furthermore, strain sweeps of supramolecular gels prepared at various concentrations of $\mathbf{1}+\mathbf{2}$ in toluene were observed (Figure S11). As expected, the $G^{\prime}$ and $G^{\prime \prime}$ values of the supramolecular gel prepared at $5.0 \mathrm{wt} \%$ were ca. 100-fold higher than that the supramolecular gel prepared at $1.0 \mathrm{wt} \%$. The $\mathrm{G}^{\prime}$ and $\mathrm{G}^{\prime \prime}$ values of the supramolecular gel prepared at $5.0 \mathrm{wt} \%$ showed a consistent tendency to those of the supramolecular gel prepared at $3.0 \mathrm{wt} \%$. At $100 \%$ of strain, all three conditions of supramolecular gel $(1 \mathrm{wt} \%, 3 \mathrm{wt} \%$, and $5 \mathrm{wt} \%$ ) reversed to $\mathrm{G}^{\prime} / \mathrm{G}^{\prime \prime}<1$. These findings indicate that supramolecular gels behave as liquids at $100 \%$ of strain. However, as the $1+2$ concentration increased, the collapse started with $\mathrm{G}^{\prime} / \mathrm{G}^{\prime \prime}<1$ at low strain. In the case of $1 \mathrm{wt} \%$ of supramolecular gel, the values of $G^{\prime}$ and $G^{\prime \prime}$ showed the lowest value, but the gel breakdown point was required at the greatest strain; therefore, the gel formed at $1 \mathrm{wt} \%$ showed the highest strength. Similar behavior was observed in the strain percentage change from $0.1 \%$ to $1000 \%$, except that the strength of supramolecular gels increased with increasing gel concentration. There is no significant change at $0.1-2 \%$ of the stain. After $2 \%$ of strain, it showed a decrease. Frequency sweeps were performed from 0.6283 to $62.83 \mathrm{rad} \mathrm{s}^{-1}$, where significant changes in the $\mathrm{G}^{\prime}$ and $G^{\prime \prime}$ values were observed by an increase of concentration $(\mathbf{1}+\mathbf{2})$ (Figure 5). When the concentration of $\mathbf{1}+\mathbf{2}$ was increased from $1 \mathrm{wt} \%$ to $3 \mathrm{wt} \%$ and $5 \mathrm{wt} \%$, the $\mathrm{G}^{\prime}$ and $\mathrm{G}^{\prime \prime}$ values increased 20-fold and 100-fold, respectively, when compared to $1 \mathrm{wt} \%$ of supramolecular gel. With increasing the concentration of gelators, the supramolecular gel leads with high strength. The $G^{\prime}$ and $G^{\prime \prime}$ values of supramolecular gels were kept constant despite a frequency change of 0.6283 to $62.83 \mathrm{rad} \mathrm{s}^{-1}$. As the reference experiment, we also measured the mechanical properties of gel obtained from pre-synthesized 3. The time-dependent storage $\left(G^{\prime}\right)$ and loss $\left(G^{\prime \prime}\right)$ moduli of the supramolecular gel prepared from pre-synthesized 3 in toluene were measured (Figure S12). As observed for in situ supramolecular gel, the $\mathrm{G}^{\prime}$ and $G^{\prime \prime}$ values of gel (1.0 wt \%) obtained from 3 reached a maximum after $50 \mathrm{~s}$. The $\mathrm{G}^{\prime}$ and $\mathrm{G}^{\prime \prime}$ values were almost same to those for in situ supramolecular gel (1 wt \%). Furthermore, no significant differences between gel obtained from pre-synthesized $3(1 \mathrm{wt} \%)$ and in situ supramolecular gel prepared from a mixed 1 ( $1 \mathrm{wt} \%, 1.0$ equiv.) and 2 (2.0 equiv.) in frequency and strain sweets were observed. These findings indicate that mixing $\mathbf{1}$ and $\mathbf{2}$ in toluene was converted to compound 3 in the gel formation. 

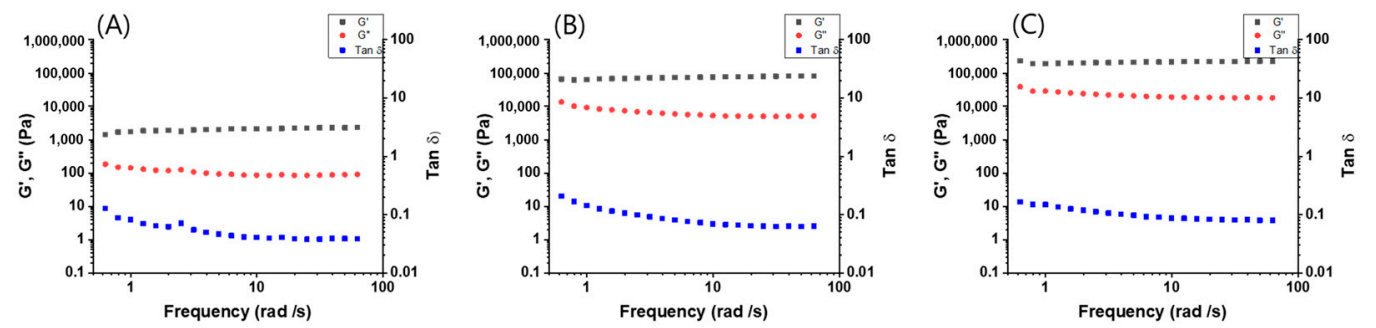

Figure 5. Frequency sweep of gels obtained from (A) 1 (1 wt \%) +2 (2 equiv.), (B) 1 (3 wt \%) + 2 (2 equiv.) and (C) $\mathbf{1}(5 \mathrm{wt} \%)+\mathbf{2}$ (2 equiv.) in toluene.

\section{Conclusions}

In this work, we have demonstrated the formation of supramolecular gel formed by mixing 1 and 2 at room temperature without catalysis. The urea groups formed by the reaction of building blocks 1 and $\mathbf{2}$ acted as a driving force for in situ supramolecular gelations. The supramolecular gels were also thermally reversible by heating and cooling. The morphology of supramolecular gels showed three-dimensional entangled network fiber structures. Furthermore, increasing the concentration of a mixed $\mathbf{1}$ and $\mathbf{2}$ increased the mechanical properties $\left(\mathrm{G}^{\prime}\right.$ and $\left.\mathrm{G}^{\prime \prime}\right)$ of the supramolecular gels prepared in toluene. The supramolecular gel prepared at $5.0 \mathrm{wt} \%$ has the greatest gel strength. Moreover, the supramolecular gels demonstrated a thixotropic effect, indicating a thermally reversible gel. Thus, we believe that the further development of in situ supramolecular gels formed at room temperature by mixing amine, hydrazine, and aldehyde derivatives will provide materials for bio-related applications by integrating functional derivatives.

Supplementary Materials: The following supporting information can be downloaded at: https: / / www.mdpi.com/article/10.3390/polym14030400/s1, Figure S1: ${ }^{1} \mathrm{H}$ NMR (500 MHz) spectrum of pre-synthesized compound 3 in DMSO- $\mathrm{d}_{6}$ at $100{ }^{\circ} \mathrm{C}$; Figure S2: IR spectrum of pre-synthesized compound 3; Figure S3: ESI MS spectrum of pre-synthesized compound $3\left(1 \times 10^{-5} \mathrm{M}\right)$ in toluene; Figure S4: IR spectra of (A) 1, (B) 2, (C) supramolecular gels prepared by $\mathbf{1}$ and $\mathbf{2}$ in toluene, Figure S5 ${ }^{1} \mathrm{H}$ NMR spectra of (A) 1, (B) 2, and (C) pre-synthesized 3 at $100{ }^{\circ} \mathrm{C}$, and (D) xerogel in DMSO-d 6 at $100{ }^{\circ} \mathrm{C}$; the xerogel sample was prepared by a mixed 1 ( $\left.3 \mathrm{wt} \%\right)+2$ (2 equivalent) in toluene; Figure S6: IR spectra of in situ gel prepared by 1 and 2 after mixing (A) 60 s, (B) 120 s, (C) $180 \mathrm{~s}$, in toluene; Figure S7: ESI mass spectrum of diluted solution $\left(1 \times 10^{-5} \mathrm{M}\right)$ prepared from in situ gel with a mixed $1(3 w t \%)+2(3 w t \%)$ in toluene; Figure S8: Temperature-dependent ${ }^{1} \mathrm{H}$ NMR spectra of xerogel sample in DMSO-d $\mathrm{d}_{6}$; the sample was prepared by a mixed 1 ( $\left.3 \mathrm{wt} \%\right)+2$ (2 equivalent) in toluene; Figure S9: Photograph of $1(0.005 \mathrm{mM})$ with $2(0.01 \mathrm{mM})(\mathrm{A})$ at room temperature, (B) at $110{ }^{\circ} \mathrm{C}$, (C), after room temperature; Figure S10: SEM images of in situ supramolecular gels prepared by $\mathbf{1}$ and 2 in (A) chloroform and (B) tetrahydrofuran; Figure S11: Time sweep (frequency $=0.6283 \mathrm{rad} \mathrm{s}^{-1}$ ) of gels obtained from (A) 1 (1 wt \%) + 2 (2 equivalent), (B) 1 (3 wt \%) + 2 (2 equivalent), (C) $1(5 \mathrm{wt} \%)+2$ (2 equivalent) in toluene; Figure S12: (A) Time- (frequency $=0.6283 \mathrm{rad} \mathrm{s}^{-1}$ ), (B) frequency-, and (C) strain-sweep at $0.1-1000 \%$ of gel obtained from (A) pre-synthesized compound $3(1 \mathrm{wt} \%)$ in toluene.

Author Contributions: Conceptualization, and methodology, J.-H.P. and M.-H.K.; writing—original draft preparation, J.-H.L.; writing-review and editing, M.-L.S. and J.-H.J.; supervision, J.-H.J. All authors have read and agreed to the published version of the manuscript.

Funding: This research was supported by the National Foundation of Korea (NRF) grant funded by the Korea government (MSIT) (2020R1A4A2002831, and 2021R1A2C2007664).

Institutional Review Board Statement: Not applicable.

Informed Consent Statement: Not applicable.

Data Availability Statement: The data presented in this study are available in article.

Conflicts of Interest: The authors declare no conflict of interest. 


\section{References}

1. Okesola, B.O.; Smith, D.K. Applying low-molecular weight supramolecular gelators in an environmental setting-Self-assembled gels as smart materials for pollutant removal. Chem. Soc. Rev. 2016, 45, 4226-4251. [CrossRef] [PubMed]

2. Lu, Q.; Han, W.J.; Choi, H.J. Smart and Functional Conducting Polymers: Application to Electrorheological Fluids. Molecules 2018, 23, 2854. [CrossRef]

3. Nguyen, M.M.; Eckes, K.M.; Suggs, L.J. Charge and sequence effects on the self-assembly and subsequent hydrogelation of Fmoc-depsipeptides. Soft Matter 2014, 10, 2693-2702. [CrossRef]

4. Nonoyama, T.; Wada, S.; Kiyama, R.; Kitamura, N.; Mredha, M.T.I.; Zhang, X.; Kurokawa, T.; Nakajima, T.; Takagi, Y.; Yasuda, K.; et al. Double-Network Hydrogels Strongly Bondable to Bones by Spontaneous Osteogenesis Penetration. Adv. Mater. 2016, 28, 6740-6745. [CrossRef] [PubMed]

5. Hopkins, A.M.; De Laporte, L.; Tortelli, F.; Spedden, E.; Staii, C.; Atherton, T.J.; Hubbell, J.A.; Kaplan, D.L. Silk Hydrogels as Soft Substrates for Neural Tissue Engineering. Adv. Funct. Mater. 2013, 23, 5140-5149. [CrossRef]

6. Huang, W.; Tarakanova, A.; Dinjaski, N.; Wang, Q.; Xia, X.; Chen, Y.; Wong, J.Y.; Buehler, M.J.; Kaplan, D.L. Design of Multistimuli Responsive Hydrogels Using Integrated Modeling and Genetically Engineered Silk-Elastin-Like Proteins. Adv. Funct. Mater. 2016, 26, 4113-4123. [CrossRef]

7. Lv, S.; Dudek, D.M.; Cao, Y.; Balamurali, M.M.; Gosline, J.; Li, H. Designed biomaterials to mimic the mechanical properties of muscles. Nature 2010, 465, 69-73. [CrossRef] [PubMed]

8. Bryant, S.J.; da Silva, M.A.; Hossain, K.M.Z.; Calabrese, V.; Scott, J.L.; Edler, K.J. Non-volatile conductive gels made from deep eutectic solvents and oxidised cellulose nanofibrils. Nanoscale Adv. 2021, 3, 2252-2260. [CrossRef]

9. Yeo, W.-H.; Kim, Y.-S.; Lee, J.; Ameen, A.; Shi, L.; Li, M.; Wang, S.; Ma, R.; Jin, S.H.; Kang, Z.; et al. Multifunctional Epidermal Electronics Printed Directly Onto the Skin. Adv. Mater. 2013, 25, 2773-2778. [CrossRef]

10. Park, J.; Kim, K.Y.; Kim, C.; Lee, J.H.; Kim, J.H.; Lee, S.S.; Choi, Y.; Jung, J.H. A crown-ether-based moldable supramolecular gel with unusual mechanical properties and controllable electrical conductivity prepared by cation-mediated cross-linking. Polym. Chem. 2018, 9, 3900-3907. [CrossRef]

11. Choudhury, N.A.; Sampath, S.; Shukla, A.K. Hydrogel-polymer electrolytes for electrochemical capacitors: An overview. Energy Environ. Sci. 2009, 2, 55-67. [CrossRef]

12. Naficy, S.; Razal, J.M.; Spinks, G.M.; Wallace, G.G.; Whitten, P.G. Electrically Conductive, Tough Hydrogels with pH Sensitivity. Chem. Mater. 2012, 24, 3425-3433. [CrossRef]

13. Sangeetha, N.M.; Maitra, U. Supramolecular gels: Functions and uses. Chem. Soc. Rev. 2005, 34, 821-836. [CrossRef] [PubMed]

14. Yu, G.; Yan, X.; Han, C.; Huang, F. Characterization of supramolecular gels. Chem. Soc. Rev. 2013, 42, 6697-6722. [CrossRef]

15. Giuri, D.; Zanna, N.; Tomasini, C. Low Molecular Weight Gelators Based on Functionalized 1-Dopa Promote Organogels Formation. Gels 2019, 5, 27. [CrossRef] [PubMed]

16. Lee, J.H.; Park, J.; Park, J.W.; Ahn, H.J.; Jaworski, J.; Jung, J.H. Supramolecular gels with high strength by tuning of calix[4]arenederived networks. Nat. Commun. 2015, 6, 6650. [CrossRef]

17. Park, J.; Lee, J.H.; Jaworski, J.; Shinkai, S.; Jung, J.H. Luminescent calix[4]arene-based metallogel formed at different solvent composition. Inorg. Chem. 2014, 53, 7181-7187. [CrossRef]

18. Skilling, K.J.; Citossi, F.; Bradshaw, T.D.; Ashford, M.; Kellam, B.; Marlow, M. Insights into low molecular mass organic gelators: A focus on drug delivery and tissue engineering applications. Soft Matter 2014, 10, 237-256. [CrossRef]

19. Liu, K.; Zang, S.; Xue, R.; Yang, J.; Wang, L.; Huang, J.; Yan, Y. Coordination-Triggered Hierarchical Folate/Zinc Supramolecular Hydrogels Leading to Printable Biomaterials. ACS Appl. Mater. Interfaces 2018, 10, 4530-4539. [CrossRef]

20. Mredha, M.T.I.; Guo, Y.Z.; Nonoyama, T.; Nakajima, T.; Kurokawa, T.; Gong, J.P. A facile method to fabricate anisotropic hydrogels with perfectly aligned hierarchical fibrous structures. Adv. Mater. 2018, 30, 1704937. [CrossRef]

21. Shi, Y.; Ma, C.; Peng, L.; Yu, G. Conductive "Smart" Hybrid Hydrogels with PNIPAM and Nanostructured Conductive Polymers. Adv. Funct. Mater. 2015, 25, 1219-1225. [CrossRef]

22. Ma, Z.; Zhang, P.; Yu, X.; Lan, H.; Li, Y.; Xie, D.; Li, J.; Yi, T. Sugar based nanotube assembly for the construction of sonication triggered hydrogel: An application of the entrapment of tetracycline hydrochloride. J. Mater. Chem. B 2015, 3, 7366-7371. [CrossRef]

23. You, Y.; Yang, J.; Zheng, Q.; Wu, N.; Lv, Z.; Jiang, Z. Ultra-stretchable hydrogels with hierarchical hydrogen bonds. Sci. Rep. 2020, 10, 11727. [CrossRef]

24. Mani, S.; Khabaz, F.; Godbole, R.V.; Hedden, R.C.; Khare, R. Structure and Hydrogen Bonding of Water in Polyacrylate Gels: Effects of Polymer Hydrophilicity and Water Concentration. J. Phys. Chem. B 2015, 119, 15381-15393. [CrossRef]

25. Oh, K.S.; Han, S.K.; Choi, Y.W.; Lee, J.H.; Lee, J.Y.; Yuk, S.H. Hydrogen-bonded polymer gel and its application as a temperaturesensitive drug delivery system. Biomaterials 2004, 25, 2393-2398. [CrossRef] [PubMed]

26. Narasimhan, B.N.; Deijs, G.S.; Manuguri, S.; Ting, M.S.H.; Williams, M.A.K.; Malmström, J. A comparative study of tough hydrogen bonding dissipating hydrogels made with different network structures. Nanoscale Adv. 2021, 3, 2934-2947. [CrossRef]

27. Sohna Sohna, J.-E.; Fages, F. A trisbipyridine tripodal ligand as toluene gelator. Phase transition-triggered binding of iron(ii). Chem. Commun. 1997, 327-328. [CrossRef]

28. Terech, P.; Allegraud, J.J.; Garner, C.M. Thermoreversible Gelation of Organic Liquids by Arylcyclohexanol Derivatives: A Structural Study. Langmuir 1998, 14, 3991-3998. [CrossRef] 
29. George, M.; Weiss, R.G. Chemically Reversible Organogels: Aliphatic Amines as "Latent" Gelators with Carbon Dioxide. J. Am. Chem. Soc. 2001, 123, 10393-10394. [CrossRef]

30. Hanabusa, K.; Suzuki, M. Physical Gelation by Low-Molecular-Weight Compounds and Development of Gelators. Bull. Chem. Soc. Jpn. 2015, 89, 174-182. [CrossRef]

31. Shao, T.; Falcone, N.; Kraatz, H.-B. Supramolecular Peptide Gels: Influencing Properties by Metal Ion Coordination and Their Wide-Ranging Applications. ACS Omega 2020, 5, 1312-1317. [CrossRef]

32. Debnath, S.; Roy, S.; Ulijn, R.V. Peptide Nanofibers with Dynamic Instability through Nonequilibrium Biocatalytic Assembly. J. Am. Chem. Soc. 2013, 135, 16789-16792. [CrossRef] [PubMed]

33. Berdugo, C.; Nalluri, S.K.M.; Javid, N.; Escuder, B.; Miravet, J.F.; Ulijn, R.V. Dynamic Peptide Library for the Discovery of Charge Transfer Hydrogels. ACS Appl. Mater. Interfaces 2015, 7, 25946-25954. [CrossRef]

34. Cheng, B.; Yan, Y.; Qi, J.; Deng, L.; Shao, Z.-W.; Zhang, K.-Q.; Li, B.; Sun, Z.; Li, X. Cooperative assembly of a peptide gelator and silk fibroin afford an injectable hydrogel for tissue engineering. ACS Appl. Mater. Interfaces 2018, 10, 12474-12484. [CrossRef] [PubMed]

35. Jadhav, S.R.; Vemula, P.K.; Kumar, R.; Raghavan, S.R.; John, G. Sugar-derived phase-selective molecular gelators as model solidifiers for oil spills. Angew. Chem. Int. Ed. 2010, 49, 7695. [CrossRef]

36. Vidyasagar, A.; Handore, K.; Sureshan, K.M. Soft Optical Devices from Self-Healing Gels Formed by Oil and Sugar-Based Organogelators. Angew. Chem. Int. Ed. 2011, 50, 8021. [CrossRef]

37. Vibhute, A.M.; Muvvala, V.; Sureshan, K.M. A Sugar-Based Gelator for Marine Oil-Spill Recovery. Angezw. Chem. Int. Ed. 2016, 55, 7782-7785. [CrossRef]

38. Chen, C.; Chen, J.; Wang, T.; Liu, M. Fabrication of Helical Nanoribbon Polydiacetylene via Supramolecular Gelation: Circularly Polarized Luminescence and Novel Diagnostic Chiroptical Signals for Sensing. ACS Appl. Mater. Interfaces 2016, 8, 30608-30615. [CrossRef]

39. Sato, H.; Yajima, T.; Yamagishi, A. Helical Inversion of Gel Fibrils by Elongation of Perfluoroalkyl Chains as Studied by Vibrational Circular Dichroism. Chirality 2016, 28, 361-364. [CrossRef]

40. Kim, C.; Kim, K.Y.; Lee, J.H.; Ahn, J.; Sakurai, K.; Lee, S.S.; Jung, J.H. Chiral Supramolecular Gels with Lanthanide Ions: Correlation between Luminescence and Helical Pitch. ACS Appl. Mater. Interfaces 2017, 9, 3799-3807. [CrossRef] [PubMed]

41. Li, S.; Zhang, L.; Jiang, J.; Meng, Y.; Liu, M. Self-Assembled Polydiacetylene Vesicle and Helix with Chiral Interface for Visualized Enantioselective Recognition of Sulfinamide. ACS Appl. Mater. Interfaces 2017, 9, 37386-37394. [CrossRef]

42. Lin, X.; Kurata, H.; Prabhu, D.D.; Yamauchi, M.; Ohba, T.; Yagai, S. Water-induced helical supramolecular polymerization and gel formation of an alkylene-tethered perylene bisimide dyad. Chem. Commun. 2017, 53, 168-171. [CrossRef] [PubMed]

43. Su, M.-M.; Yang, H.-K.; Ren, L.-J.; Zheng, P.; Wang, W. Solvent-mediated gel formation, hierarchical structures, and rheological properties of organogels. Soft Matter 2015, 11, 741-748. [CrossRef] [PubMed]

44. Panja, S.; Bhattacharya, S.; Ghosh, K. Cholesterol-Appended Benzimidazolium Salts: Synthesis, Aggregation, Sensing, Dye Adsorption, and Semiconducting Properties. Langmuir 2017, 33, 8277-8288. [CrossRef] [PubMed]

45. Alexander, S.L.M.; Korley, L.T.J. Restricting Molecular Mobility in Polymer Nanocomposites with Self-Assembling Low-MolecularWeight Gel Additives. ACS Appl. Mater. Interfaces 2018, 10, 43040-43048. [CrossRef] [PubMed]

46. Zweep, N.; Hopkinson, A.; Meetsma, A.; Browne, W.R.; Feringa, B.L.; van Esch, J.H. Balancing Hydrogen Bonding and van der Waals Interactions in Cyclohexane-Based Bisamide and Bisurea Organogelators. Langmuir 2009, 25, 8802-8809. [CrossRef]

47. de Loos, M.; Friggeri, A.; van Esch, J.; Kellogg, R.M.; Feringa, B.L. Cyclohexane bis-urea compounds for the gelation of water and aqueous solutions. Org. Biomol. Chem. 2005, 3, 1631-1639. [CrossRef]

48. Kato, T.; Kutsuna, T.; Hanabusa, K.; Ukon, M. Gelation of Room-Temperature Liquid Crystals by the Association of a trans-1,2Bis(amino)cyclohexane Derivative. Adv. Mater. 1998, 10, 606-608. [CrossRef]

49. Hanabusa, K.; Yamada, M.; Kimura, M.; Shirai, H. Prominent Gelation and Chiral Aggregation of Alkylamides Derived from trans-1,2-Diaminocyclohexane. Angew. Chem. Int. Ed. 1996, 35, 1949-1951. [CrossRef]

50. Panja, S.; Adams, D.J. Stimuli responsive dynamic transformations in supramolecular gels. Chem. Soc. Rev. 2021, 50, 5165-5200. [CrossRef]

51. Zhang, J.-Y.; Zeng, L.-H.; Feng, J. Dynamic covalent gels assembled from small molecules: From discrete gelators to dynamic covalent polymers. Chin. Chem. Lett. 2017, 28, 168-183. [CrossRef]

52. Beckers, S.J.; Parkinson, S.; Wheeldon, E.; Smith, D.K. In situ aldehyde-modification of self-assembled acyl hydrazide hydrogels and dynamic component selection from complex aldehyde mixtures. Chem. Commun. 2019, 55, 1947-1950. [CrossRef]

53. Ge, Y.; Gong, H.; Shang, J.; Jin, L.; Pan, T.; Zhang, Q.; Dong, S.; Wang, Y.; Qi, Z. Supramolecular gel based on crown-ether-appended dynamic covalent macrocycles. Macromol. Rapid Commun. 2019, 40, 1800731. [CrossRef]

54. Panja, S.; Boháčová, K.; Dietrich, B.; Adams, D.J. Programming properties of transient hydrogels by an enzymatic reaction. Nanoscale 2020, 12, 12840-12848. [CrossRef] [PubMed]

55. Panja, A.; Ghosh, K. Selective sensing of hg ${ }^{2+}$ via sol-gel transformation of a cholesterol-based compound. Supramol. Chem. 2018, 30, 722-729. [CrossRef]

56. Liang, C.; Kulchat, S.; Jiang, S.; Lehn, J.-M. Gelation-driven selection in dynamic covalent C [double bond, length as m-dash] C/C [double bond, length as m-dash] N exchange. Chem. Sci. 2017, 8, 6822-6828. [CrossRef] [PubMed] 
57. Panja, A.; Ghosh, K. Pyridyl azo-based naphthyl acetate for sensing of hydrazine and perborate in sol-gel medium. ChemistrySelect 2018, 3, 9448-9453. [CrossRef]

58. Sreenivasachary, N.; Lehn, J.-M. Gelation-driven component selection in the generation of constitutional dynamic hydrogels based on guanine-quartet formation. Proc. Natl. Acad. Sci. USA 2005, 102, 5938. [CrossRef] [PubMed]

59. Wang, G.-T.; Lin, J.-B.; Jiang, X.-K.; Li, Z.-T. Cholesterol-appended aromatic imine organogelators: A case study of gelation-driven component selection. Langmuir 2009, 25, 8414-8418. [CrossRef]

60. Sun, Y.; Zhang, Y.; Song, Y.; Liu, Y.; Zhang, X. Visual sensing of formaldehyde via a solution-to-gel transition with cholesteryl naphthalimide-based derivatives. Dyes Pigm. 2021, 193, 109546. [CrossRef]

61. Boekhoven, J.; Poolman, J.M.; Maity, C.; Li, F.; van der Mee, L.; Minkenberg, C.B.; Mendes, E.; van Esch, J.H.; Eelkema, R. Catalytic control over supramolecular gel formation. Nat. Chem. 2013, 5, 433-437. [CrossRef]

62. Maity, C.; Hendriksen, W.E.; van Esch, J.H.; Eelkema, R. Spatial structuring of a supramolecular hydrogel by using a visible-light triggered catalyst. Angew. Chem. Int. Ed. 2015, 54, 998-1001. [CrossRef] [PubMed]

63. Poolman, J.M.; Boekhoven, J.; Besselink, A.; Olive, A.G.L.; van Esch, J.H.; Eelkema, R. Variable gelation time and stiffness of low-molecular-weight hydrogels through catalytic control over self-assembly. Nat. Protoc. 2014, 9, 977-988. [CrossRef] [PubMed]

64. Trausel, F.; Versluis, F.; Maity, C.; Poolman, J.M.; Lovrak, M.; van Esch, J.H.; Eelkema, R. Catalysis of supramolecular hydrogelation. Acc. Chem. Res. 2016, 49, 1440-1447. [CrossRef] [PubMed]

65. Panja, S.; Adams, D.J. Pathway dependence in redox-driven metal-organic gels. Chem. Eur. J. 2020, 26, 6130-6135. [CrossRef] [PubMed]

66. Van Esch, J.; De Feyter, S.; Kellogg, R.M.; De Schryver, F.; Feringa, B.L. Self-Assembly of Bisurea Compounds in Organic Solvents and on Solid Substrates. Chrm. Eur. J. 1997, 3, 1238-1243. [CrossRef] 